\title{
Molecular indicators of hypoxia in the blue crab Callinectes sapidus
}

\author{
Nancy J. Brown-Peterson ${ }^{1}$, Patrick Larkin ${ }^{2}$, Nancy Denslow ${ }^{3}$, Christina King ${ }^{1}$, \\ Steve Manning ${ }^{1}$, Marius Brouwer ${ }^{1, *}$ \\ ${ }^{1}$ Department of Coastal Sciences, The University of Southern Mississippi, 703 East Beach Dr., Ocean Springs, \\ Mississippi 39564, USA \\ ${ }^{2}$ EcoArray Inc., Alachua, Florida 32615, USA \\ ${ }^{3}$ Department of Biochemistry and Molecular Biology and Center for Biotechnology, University of Florida, \\ PO Box 100156 HC, Gainesville, Florida 32610, USA
}

\begin{abstract}
Occurrence of hypoxia in estuarine waters is increasing, and recovery of impacted estuaries is slow. Detection of early effects of hypoxia is needed for timely remedial action to be taken. Here we examine the use of hypoxia-responsive gene and protein expression profiles in the blue crab Callinectes sapidus as early indicators of impacts of hypoxia. We cloned 23 potential hypoxiaresponsive genes, which were used to construct gene macroarrays. Crabs exposed to chronic hypoxia (2.5 ppm dissolved oxygen [DO]) for $15 \mathrm{~d}$ showed significant $(\mathrm{p}<0.05)$ changes in gene expression of heat shock protein 70 (Hsp 70), copper metallothionein (CuMt3), cytosolic MnSOD (cyt-MnSOD) and ribosomal proteins S15 and L23. In all cases except for CuMt3, gene expression decreased after $5 \mathrm{~d}$ exposure to hypoxia. Expression of Hsp70, CuMt3 and cyt-MnSOD also increased ( $\mathrm{p}<0.05)$ in normoxic crabs held for $15 \mathrm{~d}$, suggesting confounding effects from confinement stress. Hemocyanin protein concentrations changed significantly $(p=0.005)$ across the $15 \mathrm{~d}$ chronic hypoxia exposure. Hemocyanin in crabs exposed to $10 \mathrm{~d}$ intermittent hypoxia ( 2.5 to $8 \mathrm{ppm}$ DO over a $24 \mathrm{~h}$ cycle) did not change, but cyt-MnSOD gene expression increased significantly $(\mathrm{p}=0.037)$, whereas cytochrome $\mathrm{c}$ oxidase subunit 1 (cCox1) showed a 2.2-fold downregulation. Blue crabs collected from Pensacola Bay, Florida, showed significant $(\mathrm{p}<0.006)$ downregulation of ccox1 and cyt-MnSOD gene expression as well as hemocyanin protein levels at a diurnally hypoxic marsh site. Several hypoxiaresponsive genes (elongation factor 2, cryptocyanin, hemocyanin) were also significantly elevated $(\mathrm{p}<0.006)$ in intermolt versus premolt normoxic crabs. The identification of hypoxia-responsive genes and proteins in the blue crab is a promising first step towards the development of sensitive molecular tools for the detection of sublethal effects of hypoxia in estuarine-resident species.
\end{abstract}

KEY WORDS: Dissolved oxygen $\cdot$ Hypoxia $\cdot$ Crustacea $\cdot$ Molecular biomarker $\cdot$ Gene arrays

\section{INTRODUCTION}

The occurrence of chronic hypoxia in coastal estuaries, often driven by stratification of the water column and high temperatures, has been well documented along the Atlantic and Gulf coasts of the USA (May 1973, Officer et al. 1984, Rabalais 1998, Buzelli et al. 2002). Episodic hypoxic conditions can occur during the summer in shallow waters due to winds and tides causing periodic upwelling of hypoxic bottom waters
(Sanford et al. 1990, Bell et al. 2003a). In addition, cyclic diel patterns of hypoxic/normoxic transitions can develop, even in the absence of stratification, as a result of photosynthesis during periods of light, and respiration during periods of darkness, in combination with tidal action (Ringwood \& Keppler 2002). Increases in extent, frequency and intensity of chronic and intermittent hypoxia are often associated with eutrophication; an increase in the rate of supply of organic matter to an ecosystem, which in many cases can be linked to 
extensive coastal development (Cooper \& Brush 1993, Turner \& Rabalais 1994, Paerl et al. 1998). Microtidal estuaries, such as in the northern Gulf of Mexico, are on average much more sensitive to the effects of eutrophication than macrotidal estuaries (Monbet 1992, Cloern 2001). The occurrence of hypoxic/anoxic waters along the Gulf of Mexico is therefore common, with oxygen depletion occurring in 32 of 38 estuaries surveyed in 1994-1995 (US EPA 1999).

Bottom water hypoxia and anoxia are major factors responsible for declines in habitat quality and harvestable resources in estuarine ecosystems (Diaz et al. 1992, Justic et al. 1993). In their review on marine benthic hypoxia, Diaz \& Rosenberg (1995) conclude: 'There is no other environmental variable of such ecological importance to coastal marine ecosystems that has changed so drastically in such a short period as dissolved oxygen'. Recovery of estuaries that have been impacted by the effects of eutrophication and hypoxia may take decades (Cloern 2001, Gray et al. 2002). It is, therefore, essential to develop rapid assessment tools that can be applied to detect effects of eutrophication and hypoxia at early stages of development, so that remedial action can be taken before nearly irreversible changes have occurred.

Although estuarine organisms often face hypoxic or fluctuating hypoxic/normoxic conditions, indicators of adaptive responses to these conditions, and sublethal effects of low dissolved oxygen (DO) exposures, are largely unknown. Laboratory experiments have shown that, when possible, fish and crustaceans will avoid or move out of hypoxic conditions (Wannamaker \& Rice 2000, Wu et al. 2002). However, recent field experiments suggest that blue crabs Callinectes sapidus are often unsuccessful in escaping hypoxia and remain within hypoxic waters for several hours (Bell et al. 2003a). Prolonged exposure to hypoxia results in behavioral or physiological changes in both fishes and crustacea, such as increased ventilation frequency, cardiac output and oxygen affinity of the blood (Mangum 1997, McMahon 2001, Wu et al. 2002, Robb $\&$ Abrahams 2003). While these responses are valuable indicators of low oxygen conditions, they are not effective as biomarkers of hypoxia since they involve in situ measurements of the organisms.

Indicators of hypoxia exposure at the cellular level are needed to assess the onset, duration and severity of chronic and cyclic hypoxia. Genes that encode proteins involved in energy production, protein synthesis and degradation, lipid and carbohydrate metabolism, locomotion and contraction, and antioxidant defense are potential biomarkers of hypoxic stress (Hochachka et al. 1996). Indeed, gene and protein expression have identified potential molecular bioindicators of hypoxia in vertebrates (Airaksinen et al. 1998, Semenza 2000,
Gracey et al. 2001, Lopez-Barneo et al. 2001), and there is growing evidence that molecular indicators such as ribosomal proteins, antioxidant defense enzymes and oxygen-carrying proteins can effectively imply hypoxia exposure in invertebrates (DeFur et al. 1996, Choi et al. 2000, Brouwer et al. 2004).

The ideal model organism for examining the utility of molecular indicators of hypoxia would be an estuarine species that is frequently exposed to oxygen fluctuations and is also amenable to both laboratory and field studies. The blue crab Callinectes sapidus appears to be a good choice as a model organism since it is an estuarine resident species for most of its life cycle, and previous work in both the laboratory and the field shows this species to be tolerant of mildly hypoxic conditions (Das \& Stickle 1994, Bell et al. 2003a), with no significant differences in survival between hypoxiaexposed and normoxia-exposed crabs (Brouwer et al. 2005). The inconsistent avoidance of hypoxic conditions, as well as the ability to continue feeding under mild hypoxia (Bell et al. 2003a,b), suggests that the blue crab has developed mechanisms to survive hypoxic exposure, which can potentially be measured at a molecular level. We hypothesize that there will be unique, measurable changes in the expression of genes and proteins in the blue crab in response to hypoxic stress. In this study, we quantify changes in gene and protein expression in blue crabs exposed to chronic and intermittent hypoxic stress under laboratory conditions, and identify specific genes and proteins that could be used as biomarkers of hypoxic stress. The utility of these potential biomarkers has been examined in blue crabs sampled from cyclic hypoxic and normoxic areas in Pensacola Bay, Florida. Finally, we examined the potential confounding effects of natural biological processes, such as the molt cycle, on the expression of the hypoxia-responsive genes.

\section{MATERIALS AND METHODS}

Experimental animals and exposure methods. Blue crabs were collected in the vicinity of Ocean Springs, Mississippi, from Mississippi Sound/Davis Bayou. Adult male blue crabs (85 to $152 \mathrm{~mm}$ carapace width, 42.5 to $191.3 \mathrm{~g}$ wet weight) were maintained in the laboratory at $15 \mathrm{psu}$ and $27 \pm 1^{\circ} \mathrm{C}$ for 6 to $28 \mathrm{~d}$ prior to experimentation. During acclimation and experimentation periods, crabs were fed commercial shrimp pellets once daily. Intermolt crabs were used for laboratory studies. The designations of molt stage were according to those described by Mangum (1985). For the chronic hypoxia study, 6 crabs were placed in each of 6 hypoxic ( 2 to 3 ppm DO) and 2 normoxic (6 to 8 ppm DO) 351 tanks under flow-through conditions 
(Manning et al. 1999). Oxygen in the flow-through dilution water was maintained at supersaturation (14 ppm for hypoxic tanks and 18 to $20 \mathrm{ppm}$ for normoxic tanks) to allow for the high rates of oxygen consumption by the study crabs. Ten control (normoxic) crabs were sacrificed on Days 0 and 15 ( $\mathrm{n}=20$ total). Ten hypoxic crabs were sacrificed on each of Days 5, 10 and 15 ( $\mathrm{n}=30$ total). To examine the effects of cyclic, intermittent hypoxia, 5 crabs were placed in each of 4 cyclic DO (2 to 3 ppm DO to 8 to 9 ppm DO cycle every $24 \mathrm{~h}$ ) and 4 normoxic (8 ppm DO) 351 tanks under flow-through conditions for $10 \mathrm{~d}$. This exposure was conducted by limiting the oxygen addition to the dilution water reservoir during the evening hours, which resulted in a drop in DO in the treatment aquaria to 2 to $3 \mathrm{mg} \mathrm{l}^{-1}$ by early morning. In the morning, the frequency of oxygen aeration was increased in the reservoir, which increased the aquaria to normoxic levels by late morning or early afternoon. Ten control (normoxic) crabs were sacrificed on Days 0 and 10, and 10 intermittent hypoxic crabs were sacrificed on Days 5 and 10 (total $\mathrm{n}=20$ for each treatment). The hepatopancreas of the crabs was removed and frozen at $-70^{\circ} \mathrm{C}$ for protein analysis or stored in RNAlater (Ambion) at $-20^{\circ} \mathrm{C}$ for nucleic acid extraction.

Field collections. Blue crabs were collected using crab traps and seines on 13 September 2002 from an open bay area and a nearby marsh pond at Garcon Point in Pensacola Bay, Florida. Continuous dissolved oxygen data were collected using a Hydrolab model 4a multiprobe datasonde (Hydrolab-Hach) for $4 \mathrm{~d}$ (5 to 8 September 2002) preceding the collections of crabs from the marsh pond site. Immediately upon collection, crabs were placed on ice to immobilize them, and the hepatopancreas was removed and treated as above.

Cloning, subtractive hybridization and macroarrays of blue crab genes. Ten genes (Table 1: genes 1 to 10$)$, including heat shock protein 70 ( $H s p 70)$, mitochondrial and cytosolic manganese superoxide dismutase (mit-MnSOD and cyt-MnSOD) (Brouwer et al. 2003), hemocyanin 1 (Brouwer et al. 2002), Cu and Cd metallothionein (CUMT3 and CdMT1) (Syring et al. 2000), beta-actin, and ribosomal proteins S15, L23 and S20, were cloned and sequenced from hepatopancreas tissue of blue crab. The blue crab genes were PCRamplified and then robotically spotted in duplicate onto neutral nylon membranes together with various controls, including exogenous Arabidopsis 'spiking' genes, as described elsewhere (Larkin et al. 2003). Total hepatopancreatic mRNA was extracted from 6 to 9 blue crabs per treatment group or field collection site using Stat-60 (TEL-TEST). Genomic DNA was removed by DNase treatment and total RNA was transcribed into radiolabeled cDNA and hybridized to the membranes. Background subtraction for each cDNA spot was performed as described elsewhere (Larkin et al. 2003). The values were then normalized to a betaactin cDNA clone (see real-time PCR section for justification); the resulting values were used to determine which gene transcripts were up- or downregulated by hypoxia.

Suppressive subtractive hybridizations (SSH) were performed by EcoArray in order to increase the number of potentially hypoxia-responsive genes on the macroarray. Subtracted libraries were constructed with poly-A mRNA isolated from 7 Day 0 (control) and 7 Day 5 (hypoxic, 2 to 3 ppm DO) crabs using the Clontech PCR-Select cDNA subtraction kit following the manufacturer's recommendations. Subtracted libraries were run in both the forward and reverse directions to obtain both up- and downregulated genes. A total of 96 clones from the libraries were sequenced, and 13 clones were selected based on high homology with proteins with known functions (Table 1: genes 11 to 23) and spotted in duplicate onto expanded macroarrays as described above and used to analyze crabs after $10 \mathrm{~d}$ exposure to diurnal hypoxia and crabs collected from the field.

Table 1. Callinectes sapidus. Genes used for construction of macroarrays. Genes 1 to 10 were used in the chronic hypoxia study. Genes 1 to 23 were used in the diurnal hypoxia, field and molt cycle studies

1 Hemocyanin 1 AF249297

2 Cd metallothionein 1 (CdMT1) AF200418

3 Cu metallothionein 3 (CUMT3) AF200420 a

4 Cytosolic Mn-Superoxide dismutase (Cyt-MnSOD) AF264030a

5 Mitochondrial Mn-Superoxide dismutase (mit-MnSOD) AF264029 ${ }^{\mathrm{a}}$

6 Heat shock protein $70(H s p 70) \mathrm{AF} 427596^{\mathrm{b}} 3.01 \mathrm{e}-32^{\mathrm{c}}$

7 Beta Actin AAF70285 6 e $-60^{\mathrm{c}}$

8 Ribosomal protein S15 AAS66964 3 e-26c

9 Ribosomal protein S20 AAK95203 7 e $-42^{\mathrm{c}}$

10 Ribosomal protein L23 AAH03518 ${ }^{\mathrm{b}} 6 \mathrm{e}-50^{\mathrm{c}}$

$11 \alpha$-Amylase $S 41881^{\mathrm{b}} 5.58 \mathrm{e}-39^{\mathrm{c}}$

12 Hemocyanin 2 AF522504 $^{\mathrm{b}} 2.17 \mathrm{e}-32^{\mathrm{c}}$

13 Elongation Factor $2(E F 2)$ AAK12341 ${ }^{\mathrm{b}} 1.42 \mathrm{e}-37^{\mathrm{c}}$

14 Cathepsin L CAA59441 ${ }^{\mathrm{b}} 1.66 \mathrm{e}-40^{\mathrm{c}}$

15 Chitinase AAN74647 $1.13 \mathrm{e}-14^{\mathrm{c}}$

16 Cytochrome c Oxidase Subunit 1 (ccox1) AAG29373 ${ }^{\mathrm{b}}$ $7.67 \mathrm{e}-21^{\mathrm{c}}$

17 Cryptocyanin AAD09762 3.54 e-18

$1814 \mathrm{kDa}$ apolipoprotein BAB40966 ${ }^{\mathrm{b}} 6.62 \mathrm{e}-20^{\mathrm{c}}$

19 Apolipoprotein A1 CAC $34942^{\mathrm{b}} 1.62 \mathrm{e}-32^{\mathrm{c}}$

20 Trypsin CAA75311 $^{\mathrm{b}} 2.13 \mathrm{e}-32^{\mathrm{c}}$

21 Chymotrypsin CAA71673 ${ }^{\mathrm{b}} 0.062^{\mathrm{c}}$

22 Serine Protease NP_006016 ${ }^{\mathrm{b}} 6.86 \mathrm{e}-22^{\mathrm{c}}$

23 Oxygenase BAB13775 $1.45 \mathrm{e}-15^{\mathrm{c}}$

${ }^{a}$ GenBank accession numbers: blue crab sequences

${ }^{\mathrm{b}}$ Closest match as identified by BLASTx search

${ }^{c}$ e values (sequence similarity, Karlin \& Altschul 1990) 
Real-time PCR. To validate the use of actin as the normalizing gene and to verify the gene expression results obtained from the macroarrays, real-time PCR (Q-PCR) was run on actin and mit-MnSOD using mRNA from Day 0 normoxic and Day 5 hypoxic crabs. Primers were designed for actin (forward: 5'-ACC ATT GGC AAC GAG AGG TT-3' and reverse: 5'-TCC ATG CCC AGG AAG GAA-3') and mit-MnSOD (forward: 5'-TGA AGC CAA AGA GAA AGG TGA TG-3' and reverse: 5'-TGT CCA CCA CCA TTG AAT TTG A-3') using Primer Express software (Applied Biosystems).

To set up specific Q-PCR reactions, total RNA was reverse transcribed into cDNA using Oligo(dT) (Invitrogen), and StrataScript reverse transcriptase according to the instruction manual from Stratagene. Each real time PCR reaction contained a final volume of $25 \mu \mathrm{l}$ : $1 \mu \mathrm{l}$
CDNA, $12.5 \mu \mathrm{l} 2 \times$ SYBR green master mix (from Applied Biosystems, containing the SYBR green, buffer, Taq polymerase and dNTPs) and $250 \mathrm{nM}$ of each forward and reverse primers for each gene. In addition, PCR on minus RT controls were performed to ensure the removal of all contaminating DNA. The PCR for 18S rRNA used $1 \mu \mathrm{l}$ of the reverse-transcribed cDNA, $12.5 \mu \mathrm{l}$ of a $2 \times$ universal TaqMan master mix (Applied Biosystems), $1.25 \mu \mathrm{l}$ of $18 \mathrm{~S}$ rRNA primer plus probe (Applied Biostems) in a $25 \mu$ volume. Each sample was run in duplicate and the averages were normalized to measured $18 \mathrm{~S}$ rRNA values for each sample. 18S rRNA values did not fluctuate between treatment groups (data not shown) and, thus, were used to normalize data between sample groups. The $\Delta \Delta \mathrm{Ct}$ method was used to compare changes in gene expression between controls and treated samples.
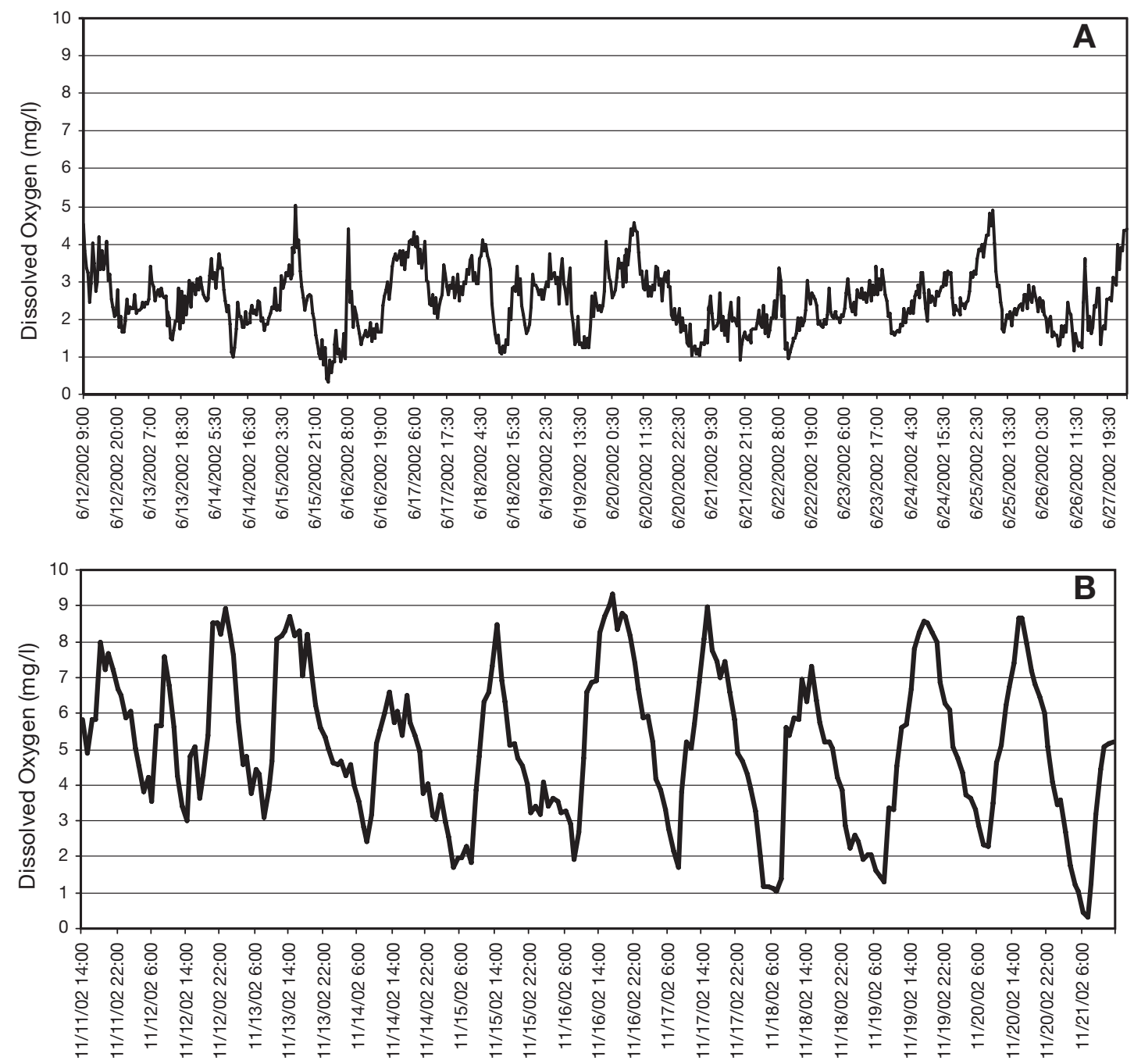

Date and Time

Fig. 1. Callinectes sapidus. Continuous oxygen profiles recorded during laboratory exposure of blue crabs to hypoxia. (A) $15 \mathrm{~d}$ chronic hypoxia exposure. (B) $10 \mathrm{~d}$ diurnal hypoxia exposure. Dates given as $\mathrm{mo} / \mathrm{d} / \mathrm{yr}$ 
Western and slot blots. Hepatopancreas tissue samples from 7 to 10 blue crabs from each treatment group or field collection site were homogenized in phosphate buffer pH 7.6 containing several proteolytic enzyme inhibitors (Lewis et al. 1999) and subjected to SDSPAGE on $12.5 \%$ polyacrylamide gels for detection of MnSOD. Separated proteins were transferred electrophoretically to PVDF membranes and visualized with a BioRad Fluor-S Multi-Imager using the Pierce SuperSignal West Dura Extend Substrate system for chemiluminescent detection of proteins. The MnSOD antibody was commercially available from Stressgen Biotechnologies. For quantification of hemocyanin tissue, homogenates and hemocyanin standards $(2,1.5,1$, $0.5,0.25,0.125$ and $0.05 \mathrm{ng}^{-1} \mathrm{l}^{-1}$ ) were denatured in SDS $\beta$-mercaptoethanol and $200 \mu \mathrm{l}$ applied to a nitrocellulose membrane in a Bio-DOT SF apparatus, followed by washing with $200 \mu$ of transfer buffer (25 mM Tris, $192 \mathrm{mM}$ glycine, $20 \mathrm{mM}$ methanol, $\mathrm{pH}$ 8.3). Hemocyanin was detected and quantified as described above, using a Callinectes sapidus antihemocyanin antibody prepared by DLAR Vivarium. Protein concentrations of the tissue homogenates were determined using the Pierce BCA assay.

Statistical analysis. Differences in gene and protein expression across time points for laboratory experiments were analyzed with ANOVA and a Bonferroni post hoc pairwise multiple comparison test. Homogeneity of variance was evaluated using Levine's test, and normality of distribution was tested with a 1 sample Kolmogorov-Smirnov test. When necessary, data were $\log _{10}$-transformed to meet ANOVA assumptions. Differences in gene and protein expression of normoxic crabs sampled at the beginning and end of each experiment were analyzed with a Student's t-test. Differences in gene and protein expression for field-collected crabs were determined with a Student's $t$-test or a MannWhitney Rank Sum test, when $t$-test assumptions were violated. Differences between $\Delta \mathrm{Ct}$ normalized values determined by Q-PCR for actin and mit-MnSOD of Day 0 normoxic and Day 5 hypoxic crabs were analyzed with a Student's $t$-test. All analyses were performed using SPSSW 11.5 (SPSS Inc. 2002), and results were considered significant if $\mathrm{p}<0.05$.

\section{RESULTS}

\section{Laboratory experiments}

Oxygen profiles of blue crabs exposed to chronic hypoxia showed minor fluctuations between 2 and $3 \mathrm{ppm}$, with an overall mean DO of $2.46 \pm 0.04 \mathrm{mg} \mathrm{l}^{-1}$ during the course of the $15 \mathrm{~d}$ experiment (Fig. 1A). Chronic hypoxia induced significant changes in the expression of several blue crab genes that were spotted onto a 10 gene macroarray: ribosomal proteins S15 $\left(F_{4,37}=2.727 ; \mathrm{p}=0.046\right)$ and L23 $\left(F_{4,37}=2.905 ; \mathrm{p}=\right.$ 0.037), Hsp70 $\left(F_{4,37}=23.48 ; \mathrm{p}<0.001\right), C u M T 3\left(F_{4,37}=\right.$ $4.169 ; \mathrm{p}=0.008)$, and cyt-MnSOD $\left(F_{4,37}=5.598 ; \mathrm{p}=\right.$ $0.001)$; and marginally significant changes in mit$\operatorname{MnSOD}\left(F_{4,37}=2.639 ; \mathrm{p}=0.051 ;\right.$ Fig. 2). The Hsp70 data are not shown in Fig. 2, since the changes in relative expression levels $(0.41-, 3.12-, 3.93$ - and 5.24-fold on Days 5, 10, 15 and 15 normoxic, respectively) would obscure the smaller changes observed for the other

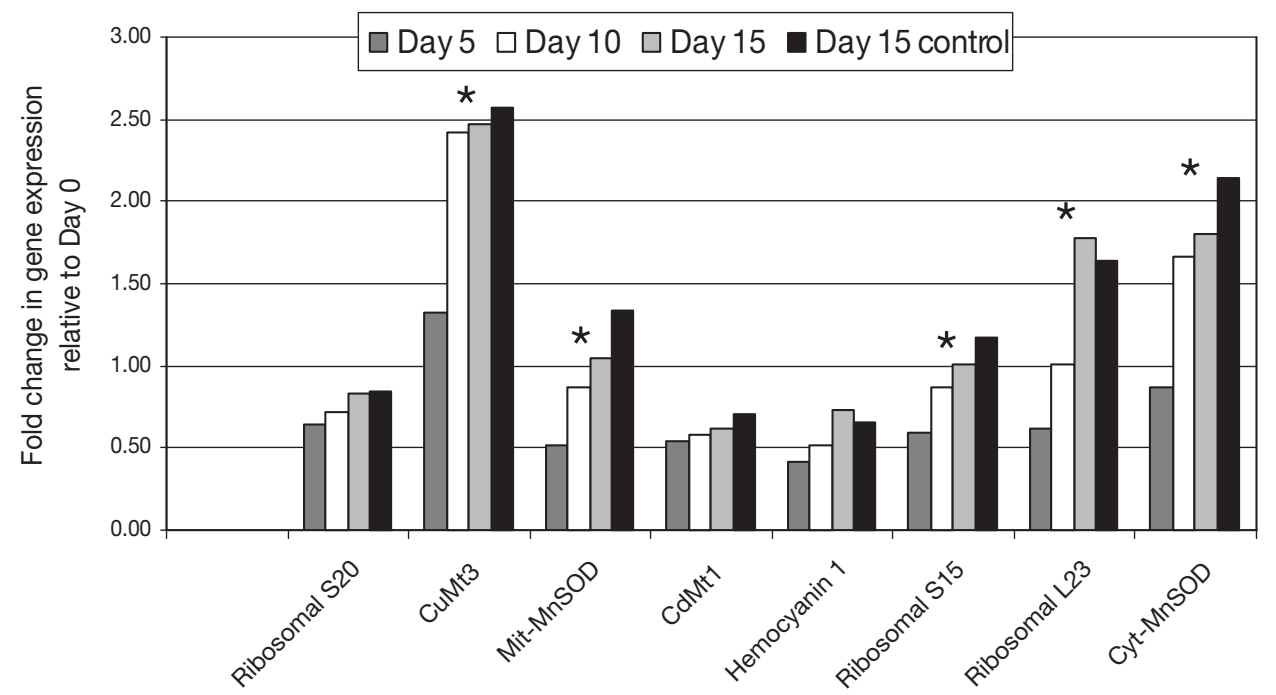

Fig. 2. Callinectes sapidus. Changes in expression of blue crab genes, relative to Day 0, in response to chronic hypoxia (2.5 ppm dissolved oxygen). Day 15 controls represent crabs exposed to normoxia (8 ppm dissolved oxygen) for 15 d. Expression data were normalized to actin. *: significant changes in gene expression over time, as determined by ANOVA 


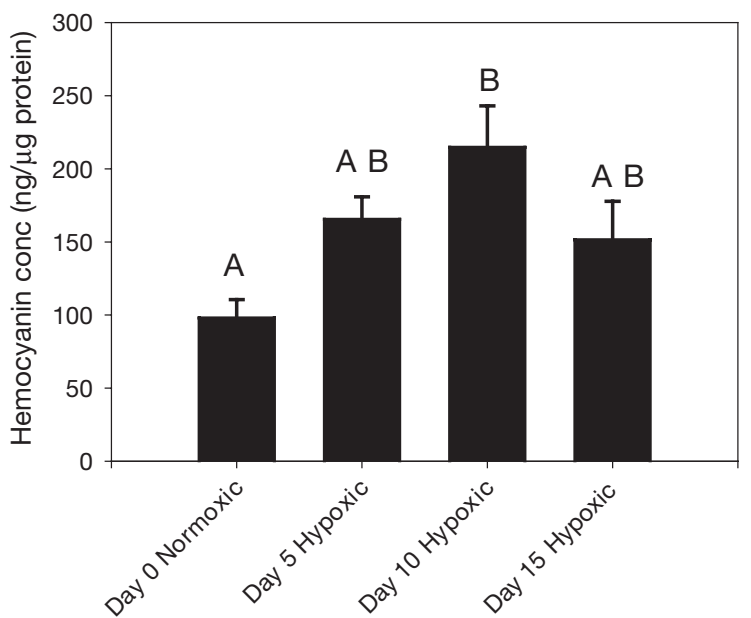

Fig. 3. Callinectes sapidus. Effect of chronic hypoxia (2.5 ppm dissolved oxygen; $34 \%$ saturation; salinity $15 \mathrm{psu}^{2} 27^{\circ} \mathrm{C}$ ) on hemocyanin protein levels (mean $+\mathrm{SE}$ ) in blue crab hepatopancreas. Different letters indicate means significantly different from each other, based on a Bonferroni post hoc test of ANOVA

genes. Expression of all genes, except for CuMT3, was downregulated at $5 \mathrm{~d}$. Expression of $C d M T 1(\mathrm{p}=$ 0.658), ribosomal protein $\mathrm{S} 20(\mathrm{p}=0.143)$ and hemocyanin $(\mathrm{p}=0.111)$ remained relatively constant throughout the $15 \mathrm{~d}$ experimental period.

The significant differences in gene expression of Hsp 70, CuMT3 and cyt-MnSOD may be partially due to confinement stress during the $15 \mathrm{~d}$ experiment, since their expression was also significantly upregulated in the $15 \mathrm{~d}$ normoxic crabs compared to the $0 \mathrm{~d}$ normoxic crabs: Hsp70 $\left(t_{13}=-2.551 ; \mathrm{p}=0.047\right)$, CuMT3 $\left(t_{15}=-2.893 ; \mathrm{p}=0.019\right)$ and cyt-MnSOD $\left(t_{15}=-3.431\right.$; $\mathrm{p}=0.004)$. Changes in expression of ribosomal S15 and L23, and mit-MnSOD appear to be a response to the hypoxia treatment only, since there was not a significant difference in gene expression between normoxic crabs at Day 0 and Day 15: S15 $\left(t_{13}=0.797 ; \mathrm{p}=0.440\right)$, L23 $\left(t_{15}=-1.254 ; \mathrm{p}=0.229\right)$ and mit-MnSOD $\left(t_{14}=\right.$ $-1.126 ; \mathrm{p}=0.279$ ).

Hemocyanin protein expression showed significant differences $\left(F_{3,35}=5.169 ; \mathrm{p}=0.005\right)$ across the $15 \mathrm{~d}$ chronic hypoxia exposure, with highest expression on Day 10 compared to the Day 0 normoxic crabs (Fig. 3). There was no difference in hemocyanin protein expression for normoxic crabs on Days 0 and $15\left(t_{15}=\right.$ $-1.390 ; \mathrm{p}=0.185$ ). The MnSOD protein expression was not quantified due to the appearance of a higher molecular weight MnSOD protein aggregate $(\sim 70$ to $90 \mathrm{kDa}$ ) in hypoxia-exposed crabs compared to normoxic crabs, which showed the normal 22 and $25 \mathrm{kDa}$ bands, corresponding to the mitochondrial and cytosolic forms of blue crab MnSOD (Brouwer et al. 2003). The higher molecular weight, crosslinked bands were predominant in crabs exposed to hypoxia for 5,10 or $15 \mathrm{~d}$, and rarely occurred in the normoxic crabs (Fig. 4A).

Blue crabs exposed to cyclic, diurnal fluctuations in DO for 5 and $10 \mathrm{~d}$ (10 d oxygen profile shown in Fig. 1B) showed no significant differences in gene or protein expression during the time-course of the experiment (data not shown). Furthermore, there were no significant differences in gene or protein expression values between the Day 0 and Day 10 normoxic crabs, suggesting that confinement stress was not a factor in this $10 \mathrm{~d}$ experiment. Finally, although some crabs in all treatments during the cyclic DO study exhibited crosslinked MnSOD bands, the non-crosslinked bands predominated at all time points (Fig. 4B).
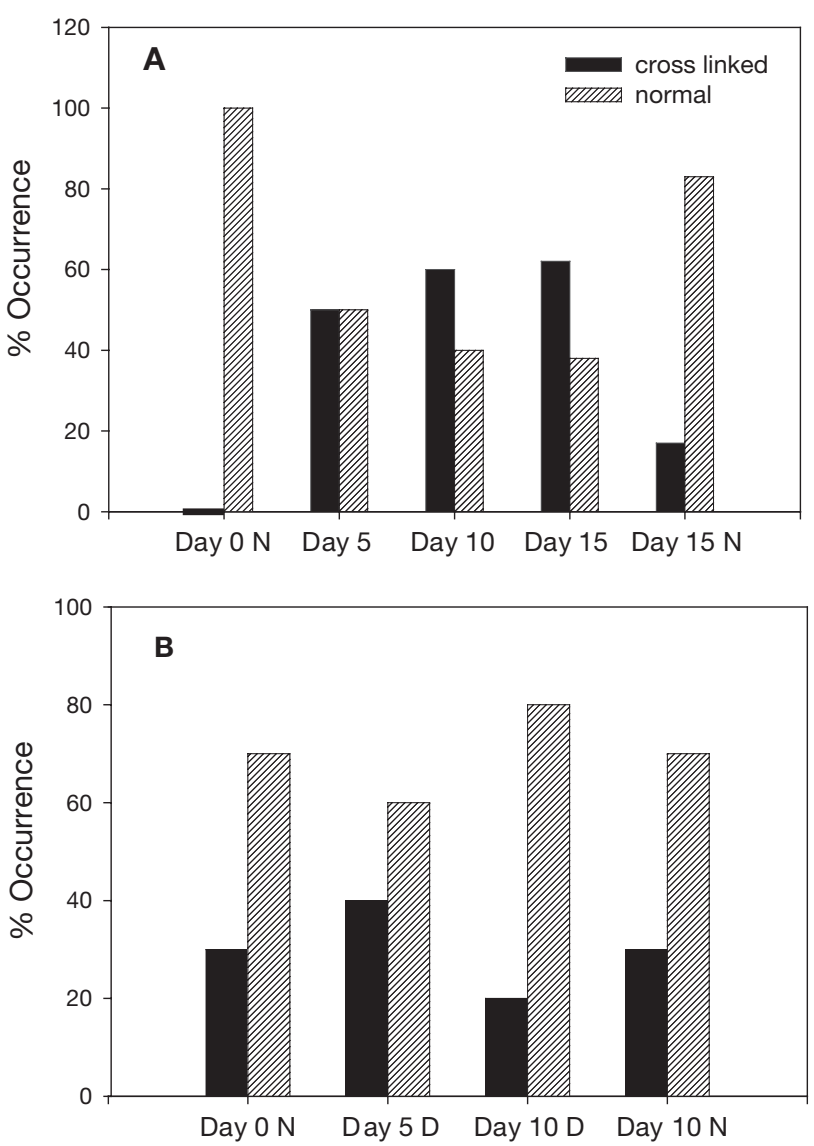

Fig. 4. Callinectes sapidus. Percentage occurrence of normaland high-molecular-weight crosslinked MnSOD proteins in hepatopancreas of blue crabs exposed to hypoxia under laboratory conditions. (A) Crabs exposed to chronic hypoxia (2.5 ppm dissolved oxygen [DO]) for $15 \mathrm{~d}$. Day $0 \mathrm{~N}$ and Day 15 $\mathrm{N}$ represent crabs exposed to normoxia (8 ppm DO) and sampled at Days 0 and 15, respectively. $\mathrm{n}=10$ for each time point. No crabs had crosslinked MnSOD at Day 0. (B) Crabs exposed to diurnally fluctuating hypoxia (2.5 to $8 \mathrm{ppm}$ DO cycle in a $24 \mathrm{~h}$ period) for $10 \mathrm{~d}$. Day $0 \mathrm{~N}$ and Day $10 \mathrm{~N}$ represent crabs exposed to normoxia (8 ppm DO) and sampled at Days 0 and 10 , respectively. $n=10$ for each time point 


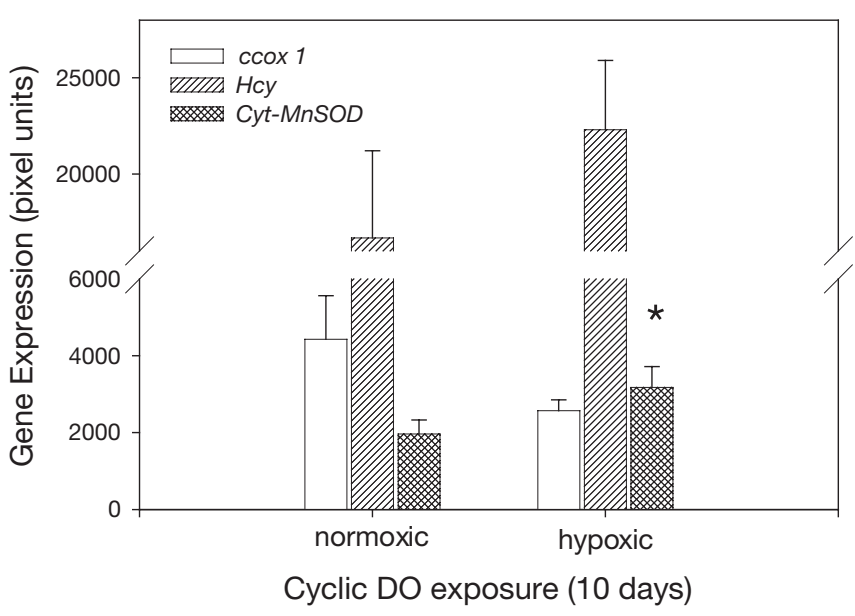

Fig. 5. Callinectes sapidus. Gene expression (mean $+\mathrm{SE})$ of cytochrome c oxidase 1 (CCOx1), hemocyanin (Hcy) and cytosolic MnSOD (cyt-MnSOD) from blue crabs exposed to normoxia (8 ppm dissolved oxygen [DO]) or diurnal hypoxia ( 2.5 to $8 \mathrm{ppm}$ DO cycle in a $24 \mathrm{~h}$ period) for $10 \mathrm{~d}$ under laboratory conditions. *: $\mathrm{p}<0.05$

The lack of significant changes in gene expression in the diurnal experiments using macroarrays with the limited set of genes used for the chronic hypoxia studies suggested additional genes should be analyzed. Subtractive hybridization identified several potentially hypoxia-responsive genes (Table 1: genes 11 to 23). Use of expanded macroarrays with these 13 additional genes showed that expression levels of several of the new genes on the arrays were low, with intensities of hybridized products only slightly above background (Table 1: genes 18 to 23). These observations suggest that these genes are not highly expressed. Of the genes that had high signal intensities on the membranes (Table 1: genes 1 to 17), cytochrome c oxidase subunit 1 (cCox1) appeared to be responsive to diurnal changes in DO, and was downregulated 2.2-fold in crabs exposed to $10 \mathrm{~d}$ diurnal hypoxia when compared to $10 \mathrm{~d}$ normoxic crabs, although this difference was not significant $\left(t_{16}=1.432 ; \mathrm{p}=0.171\right)$ (Fig. 5). Levels of expression of $c y t-M n S O D$ were significantly increased 1.6-fold $\left(t_{14}=2.296 ; \mathrm{p}=0.037\right)$ and expression of both hemocyanin genes 1 and 2 were slightly, but not significantly, higher in crabs exposed to $10 \mathrm{~d}$ diurnal hypoxia fluctuations when compared to normoxic controls (Fig. 5).

\section{Real-time PCR validation}

Q-PCR was used to verify the use of beta-actin as the internal standard for normalization of the arrays and to validate the gene expression results from the macroar- ray using mit-MnSOD as a test case. There was a nonsignificant $(\mathrm{p}=0.210)$ 1.4-fold increase in actin expression after $5 \mathrm{~d}$ hypoxia exposure, indicating that actin did not change during hypoxia exposure. In addition, when the macroarray expression data of the chronic hypoxia study were normalized to the exogenous Arabidopsis 'spiking' genes instead of actin, no significant changes in actin expression were observed from Day 0 to Day 5 ( $t$-test; $\mathrm{p}=0.921$ ) or across the time-course of the study (ANOVA; $\mathrm{p}=0.097$ ), further validating the use of actin as the internal normalization standard.

Q-PCR data showed a 1.6-fold decrease in expression of mit-MnSOD following $5 \mathrm{~d}$ hypoxia exposure. Although this was not a significant difference $(\mathrm{p}=$ $0.284)$, the trend of decreased gene expression in hypoxia, determined by Q-PCR, mirrors the decrease in gene expression seen with macroarrays with $5 \mathrm{~d}$ hypoxia exposure (1.95-fold decrease, Fig. 2).

\section{Field experiments}

The marsh pond site at Garcon Point in Pensacola Bay exhibited consistent diurnal fluctuations in DO during early September, with oxygen $<2.5 \mathrm{mg} \mathrm{l}^{-1}$ (<37\% saturation) and as low as $\sim 1.5 \mathrm{mg} \mathrm{l}^{-1}$ (22\% saturation) between 20:00 and 04:00 h daily (Fig. 6A). In contrast, DO measurements from surface to bottom at the open bay site exhibited values ranging from 4.94 to $5.19 \mathrm{mg} \mathrm{l}^{-1}$ (>75\% saturation), and we consider this a normoxic site. The $\mathrm{pH}$ at both sites was nearly the same throughout the water column: $\mathrm{pH} 7.90$ for marsh pond and $\mathrm{pH} 7.75$ for the open bay site, and salinity was 28.7 psu, from surface to bottom, for both sites. All of the genes, with the exception of CuMT3, were expressed at a lower level in the marsh pond crabs compared to open bay crabs. Although this overall pattern of gene expression was unmistakable, the differences between individual genes were often not significant. There were significant differences in gene expression for CCOX1 and cyt-MnSOD between the open bay and marsh pond sites $\left(U=2.0, \mathrm{p}=0.006 ; t_{13}=\right.$ 3.306, $p=0.006$, respectively, Fig. 6B), with downregulation of expression of both genes evident at the diurnally hypoxic marsh site. Expression of 2 distinct hemocyanin genes was also downegulated at the marsh site (Fig. 6B), although the differences were not significant. Hemocyanin protein expression was, however, significantly lower at the marsh site $\left(t_{26}=-5.657\right.$, $\mathrm{p}<0.001$ ) when compared to the normoxic open bay site (Fig. 6C).

Examination of the macroarray membranes from the field experiments revealed 2 unique gene expression patterns among crabs at the same site, suggesting that there might be 2 different 'groups' of crabs occurring 

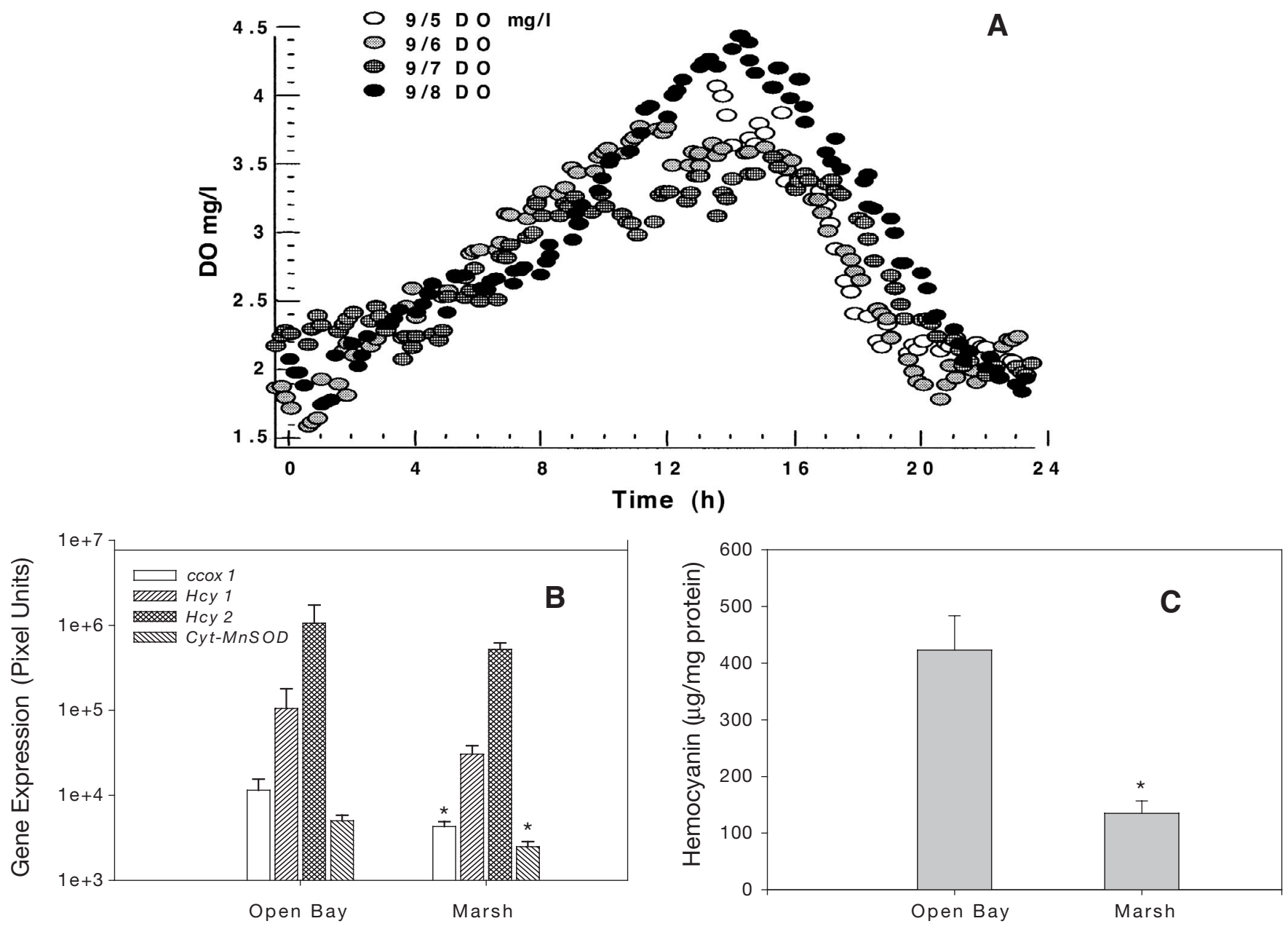

Fig. 6. (A) Diurnal dissolved oxygen (DO) profile from marsh pond site at Garcon Point, Pensacola Bay, Florida in September 2002. (B) Gene expression (mean + SE) of cytochrome c oxidase 1 (ccox1), hemocyanin 1 and 2 (Hcy 1, Hcy 2), and cytosolic MnSOD (cyt-MnSOD) from blue crabs collected from open bay and marsh sites at Garcon Point, Pensacola Bay, Florida in September 2002. (C) Hemocyanin protein concentration (mean + SE) of blue crabs collected from open bay and marsh sites at Garcon Point, Pensacola Bay, Florida in September 2002. * $p<0.01$

at the field sites. For example, some crabs from the open bay site showed much higher expression of the EF2, cryptocyanin and hemocyanin genes than other crabs collected at the same time from the same area (Fig. 7); similar differences were seen in the marsh pond crabs. Thus, there appear to be endogenous factors, unrelated to DO profile, that may affect the expression of some genes.

\section{Molt cycle experiment}

To investigate the hypothesis that endogenous factors, such as molt cycle, may differentially affect gene expression, we examined gene expression profiles of 5 premolt and 6 intermolt crabs held under normoxic conditions. The results showed EF2 expression levels in intermolt crabs were 180-fold greater than in premolt crabs $\left(t_{8}=-5.233 ; \mathrm{p}=0.001\right)$ (Fig. 8). Expression of hemocyanin 1 and 2 and cryptocyanin was 15 -fold $\left(t_{9}=\right.$ -3.694; $\mathrm{p}=0.005), 37$-fold $\left(t_{8}=-4.077 ; \mathrm{p}=0.004\right)$ and 100 -fold $\left(t_{7}=-3.834 ; \mathrm{p}=0.006\right)$ higher, respectively, in intermolt crabs compared to premolt crabs. Several other genes appeared to be 'molt independent' as there was no difference in gene expression between premolt and intermolt crabs: $\operatorname{CCOX} 1(\mathrm{p}=0.163)$, ribosomal proteins S15, S20 and L23 ( $\mathrm{p}=0.114, \mathrm{p}=0.078$ and $\mathrm{p}=0.229)$, cyt-MnSOD ( $\mathrm{p}=0.101), \operatorname{mit}-\operatorname{MnSOD}(\mathrm{p}=$ 0.909 ) and $H s p 70$ ( $\mathrm{p}=0.793$; Fig. 8). Thus, variations in expression of these genes should indicate exogenous, rather than endogenous, changes in the crab's environment. 


\section{DISCUSSION}

Our data indicate that changes in gene and protein expression in blue crab hold promise as molecular indicators for detection of exposure to chronic hypoxia and, to a lesser extent, to diurnal, intermittent, hypoxia. It is well established that an initial response to hypoxic stress in vertebrates involves a rapid inhibition of protein synthesis (Hochachka et al. 1996, Hochachka \& Lutz 2001), a mechanism to reduce energy demand under conditions of reduced ATP production. This inhibition in protein synthesis was demonstrated in blue crab by the downregulation of gene expression of ribosomal proteins after $5 \mathrm{~d}$ exposure to chronic hypoxia. Similar downregulation of ribosomal proteins has also been reported in hypoxiaexposed fish (Gracey et al. 2001, Ton et al. 2003). Downregulation of mitochondrial MnSOD is also a typical cellular response to hypoxia in both vertebrates and invertebrates (Russell et al. 1995, Choi et al. 2000),

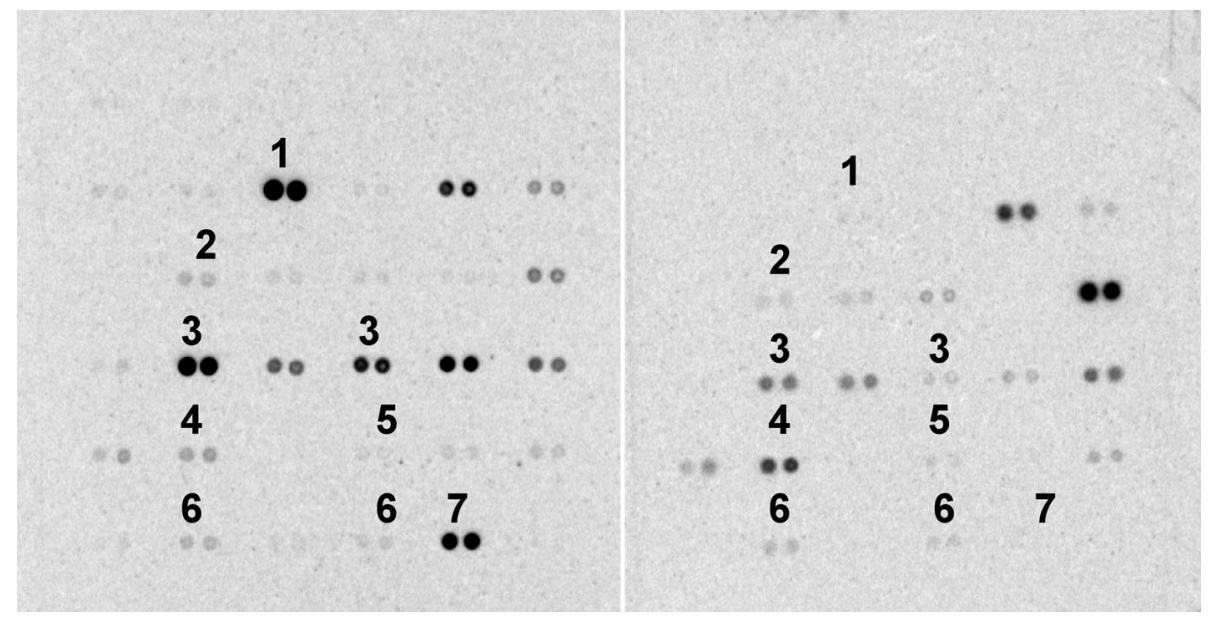

Fig. 7. Callinectes sapidus. Membranes showing gene expression profiles of representative blue crabs captured at an open bay site at Garcon Point, Pensacola Bay, Florida in September 2002. Note the differences in gene expression of some genes between individuals from the same site. 1: elongation factor $2 ; 2$ : cytochrome c oxidase subunit 1 ; 3 : hemocyanin; 4 : Cu metallothionein; 5: cytosolic MnSOD; 6: ribosomal proteins; 7: cryptocyanin

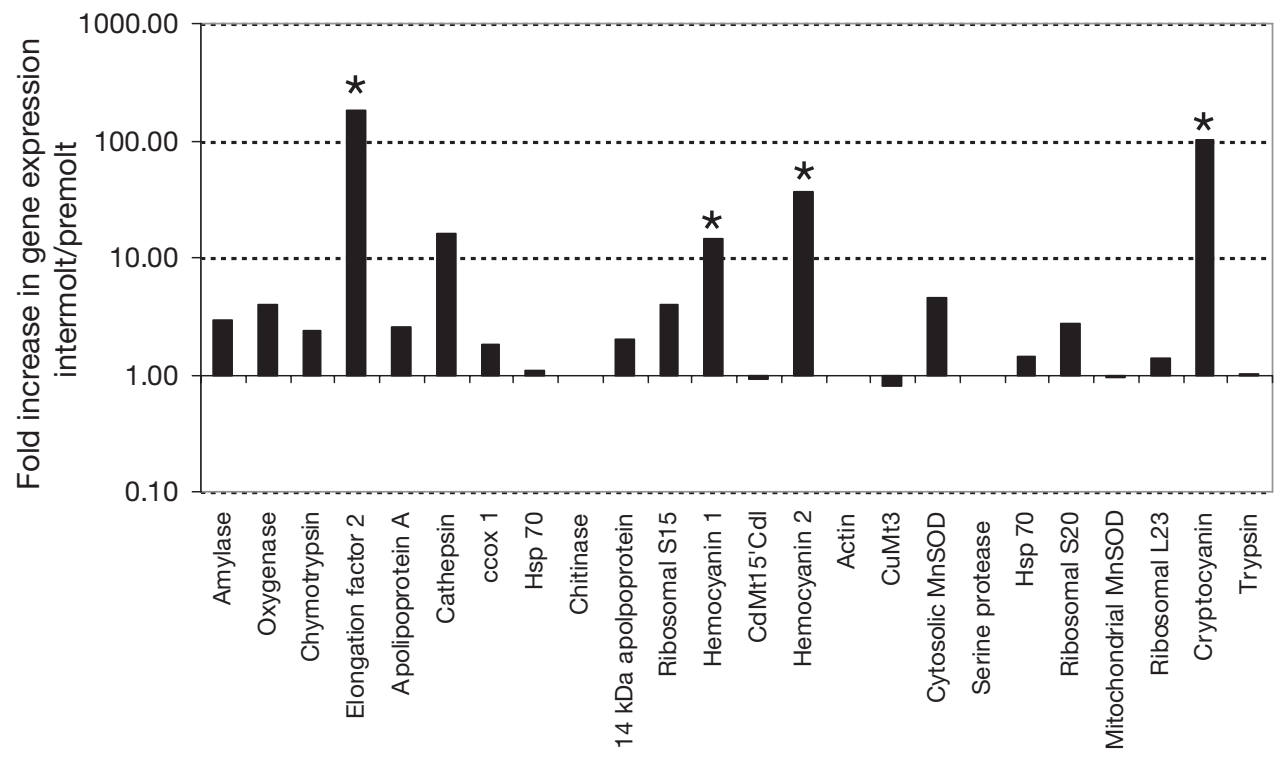

Fig 8. Callinectes sapidus. Comparison of gene expression levels in intermolt and premolt blue crabs held under normoxic conditions. Elongation factor 2, hemocyanin 1 and 2, and cryptocyanin expression levels were 180-, 15-, 37- and 100-fold higher, respectively, in intermolt crabs compared to premolt crabs. ${ }^{*} \mathrm{p}<0.05$ 
presumably due to reduced production of superoxide radicals under hypoxic conditions. In blue crab, expression of mitochondrial MnSOD was lower at both 5 and $10 \mathrm{~d}$ exposure to hypoxia than in normoxic conditions. In contrast, gene expression of the unusual cytosolic form of this enzyme increased significantly during the time-course of the chronic hypoxia exposure. Similarly, expression of the chaperone protein Hsp70, a major player in cellular stress defense (Kultz 2003), was elevated after 10 and 15 d hypoxia exposure, comparable to hypoxia-induced increases reported in vertebrates (Benjamin et al. 1990, Ton et al. 2003). It is interesting to note that after $15 \mathrm{~d}$ exposure to chronic hypoxia, the expression level of several genes had returned to normoxic levels. This may represent arrival at a new, hypometabolic steady state as has been demonstrated in other hypoxia-tolerant organisms (Hochachka \& Lutz 2001).

Protein degradation is also severely reduced during hypoxic exposure as a further energy-saving mechanism (Hochachka et al. 1996, Hochachka \& Lutz 2001). It could be argued, therefore, that proteins 'live longer' under hypoxic conditions. This phenomenon might explain why hemocyanin protein levels increased in response to hypoxia, whereas hemocyanin mRNA levels decreased.

The molecular responses of blue crab to intermittent hypoxia, using the set of hypoxia-responsive genes, were less pronounced and appeared to differ from the responses to chronic hypoxia. The downregulation of protein synthesis that occurred in response to chronic hypoxia, as evidenced by inhibition of transcription of ribosomal protein genes, was not observed in intermittent hypoxia, suggesting energy conservation is not as important under fluctuating conditions when oxygen is occasionally available.

The need to protect tissues from oxidative damage resulting from reperfusion with oxygen following hypoxia is critical in intermittent hypoxia. The antioxidant enzyme MnSOD plays an important role in this process (Czyzyk-Krzeska 1997). Blue crabs exposed to intermittent hypoxia for $10 \mathrm{~d}$ showed a 1.6-fold increase in cyt-MnSOD transcription, whereas transcription of the mit-MnSOD gene had increased 1.7-fold. In contrast, in crabs exposed to chronic hypoxia for $10 \mathrm{~d}$, transcription of mit-MnSOD had decreased marginally by 1.2 -fold. There is also a difference in the structure of the MnSOD protein between chronic and intermittent hypoxia, with the crosslinked, high molecular weight species predominant only during chronic hypoxia, and the normal, monomeric form most common during normoxia or intermittent hypoxia. At present, we do not have an explanation for the unexpected crosslinking phenomenon nor for its biological significance, although it is intriguing that similar crosslinking of MnSOD occurs in the grass shrimp Palaemonetes pugio exposed to hypoxic conditions (C. King \& M. Brouwer unpubl. data).

cCox1 was downregulated 2.2-fold in blue crab after $10 \mathrm{~d}$ exposure to intermittent hypoxia and 2.7 -fold in crabs from a field site experiencing cyclic DO patterns. Similar decreases in $\operatorname{cox} 1$ have been reported for zebrafish and Gillichthus mirabilis exposed to hypoxic conditions (Gracey et al. 2001, Ton et al. 2003). Taken together, our data suggest that some of the genes that are responsive to chronic hypoxia are also responsive to intermittent hypoxia. For future studies, it will be necessary to increase the number of genes on the macroarrays that are responsive to intermittent hypoxia by performing subtractive hybridizations using mRNA from control crabs and crabs that have been exposed to intermittent hypoxia.

Verification of the array data using Q-PCR confirmed that beta-actin expression did not change with hypoxic exposure, as also demonstrated for Gillichthus mirabilis exposed to hypoxia (Gracey et al. 2001), and is thus useful for normalization of the arrays. Q-PCR also validated the 1.6-fold downregulation of mit$M n S O D$ under chronic hypoxia observed in the macroarray data, indicating that the macroarray procedures used in the present study are sensitive enough to detect changes in gene transcription of 1.6-fold or greater.

Due to several confounding factors, interpretation of our data should be exercised with great care. For example, the significant differences in expression of $\mathrm{CuMt3}$, Hsp70 and cyt-MnSOD between normoxic crabs on Days 0 and 15 suggest that the crabs were experiencing stress by factors other than low dissolved oxygen levels, probably caused by their confinement in the small experimental chambers. It is well known that both metallothionein and $H s p 70$ can be induced by restraint stress (Blake et al. 1991, Ghoshal et al. 1998); thus, although expression of $H s p 70$ has been shown to increase in response to hypoxia (Benjamin et al. 1990, Ton et al. 2003), confinement stress may also have contributed to the significant differences we observed in Hsp70 expression in blue crab. The lack of a significant increase in expression of CuMT3, Hsp70 and cyt-MnSOD after a $10 \mathrm{~d}$ confinement in the intermittent hypoxia study, and the observation that expression of the 3 genes was not significantly different from Day 0 crabs after $10 \mathrm{~d}$ exposure to chronic hypoxia, suggests confinement stress may have become the overriding factor responsible for the observed increases in CuMT3, Hsp70 and cyt$M n S O D$ expression at Day 15 of the chronic hypoxia study. We cannot, however, exclude the possibility at this time that these genes may also exhibit changes after a $5 \mathrm{~d}$ exposure to normoxia, although this seems unlikely since there was no effect at $10 \mathrm{~d}$ normoxia. 
These results highlight the importance of carefully controlling for extraneous variables, and also suggest that blue crab may not be the ideal organism for laboratory work involving complex exposure regimens such as diurnal DO cycles, which require exposure aquaria of relatively small volumes in order to be able to establish, control and maintain the desired daily changes in DO.

When examining and interpreting changes in gene expression in response to a treatment, it is necessary to know the natural biological variability of the gene expression profiles in the absence of the treatment variable. As a case in point, expression of 3 of the hypoxia-responsive genes identified by subtractive hybridization and/or macroarrays, for example those encoding for hemocyanin, cryptocyanin and EF2, were also found to change in the absence of hypoxia during the crab's molt cycle. Hemocyanin mRNA levels were significantly lower in premolt than in intermolt crabs, which confirms earlier studies showing hemocyanin mRNA levels decrease from intermolt through ecdysis (Brouwer et al. 2002).

Cryptocyanin and hemocyanin represent the most abundant clones found in the subtracted library of hypoxia-downregulated genes obtained from crabs exposed to chronic hypoxia for $5 \mathrm{~d}$. This strongly suggests that the transcription of both genes is downregulated in response to $5 \mathrm{~d}$ of chronic hypoxia, as confirmed for hemocyanin by macroarrays. Cryptocyanin is a copper-free hemocyanin-like protein that probably functions as an extracellular matrix protein. Its concentration in the hemolymph has been shown to increase dramatically in premolt Dungeness crabs Cancer magister (Terwilliger et al. 1999). However, we found gene expression to be 60 -fold higher in intermolt than premolt blue crabs. This apparent discrepancy may be due to the time lapse between protein synthesis in the hepatopancreas and appearance of the protein in the hemolymph. It appears that cryptocyanin, like hemocyanin, is both hypoxia- and molt cycle-sensitive.

Elongation factor 2 (EF2) was obtained from a subtracted library of hypoxia-upregulated genes. Overproduction of elongation factors such as EF1 in response to sustained hypoxia has also been observed in plants, where it is required for restoration of protein synthesis, which is inhibited after short-term hypoxia exposure (Vayda et al. 1995, Hochachka \& Lutz 2001). EF2 of the crab is also molt cycle-sensitive. Its expression level was found to be 180-fold higher in premolt crabs compared to intermolt crabs.

The confounding effects of molt cycle-induced responses in gene expression make interpretation of field data challenging. It is obviously imperative to collect intermolt crabs only, but even then changes in preparation for molt at the molecular level may already have occurred before premolt crabs can be identified by morphological characteristics. It will, therefore, be necessary to consider the use of hypoxia-responsive genes whose expression is also molt cycle-responsive with great caution. This concern is supported by our field array data, which showed wide variation of hemocyanin, cryptocyanin and EF2 gene expression levels in crabs captured from the same site. It will be best to focus on genes that are hypoxia-responsive, but that do not change during the molt cycle. A few of those, such as CCOX1, ribosomal proteins S15, S20 and L23, cyt-MnSOD and mit-MnSOD, have been identified in this study. Additional, maybe more sensitive genes exhibiting greater changes in response to hypoxia can be identified by expanding the rather limited gene arrays used in this study, with cDNA from clones from the 2 hypoxia-responsive subtracted libraries and with new clones obtained from subtractive hybridization experiments using intermittent hypoxia as the stressor.

Based on the results obtained with the blue crab, we are expanding our studies on the effects of hypoxia on estuarine crustacea to the grass shrimp Palaemonetes pugio, a small, easy to maintain, ubiquitous marsh resident species. We have shown the shrimp to be tolerant to hypoxia as low as $1.5 \mathrm{ppm}$ DO for up to $6 \mathrm{wk}$ and have identified 75 hypoxia-responsive genes in this species (Brouwer et al. 2005). Reproduction can be easily quantified, and appears to be affected by hypoxia (Brouwer et al. 2005). The ability to quantify reproduction as well as gene and protein expression in grass shrimp will link molecular and whole-animal responses to hypoxia, and will provide an opportunity to incorporate information obtained from these molecular and whole-animal indicators into models to predict population-level effects (Rose 2000, Rose et al. 2003, Brouwer et al. 2005).

Gene arrays have been used extensively in mammalian environmental toxicology. The application of gene array technology to study effects of environmental contaminants and hypoxia in aquatic systems is in the early stages of development and has been limited to fish (Gracey et al. 2001, Hogstrand et al. 2001, Larkin et al. 2003, Ton et al. 2003, Williams et al. 2003). The identification of hypoxia-responsive genes and proteins of the blue crab in this study constitutes an important first step toward a better understanding of the benefits and problems associated with the use of gene and protein expression profiles in estuarine invertebrates as molecular indicators of environmental conditions. Although many problems still have to be overcome, gene array technology will no doubt become routine for assessing a variety of bioindicators in estuarine species in the next decade and will result in the development of sensitive early-warning signals of incipient ecological change, especially if the molecular signals can be linked to reduced fitness of the organism. 
Acknowledgements. We thank T. Brouwer, W. Grater, V. Pashal and B. Carter for their expert help with cDNA cloning, sequencing, Q-PCR analysis and subtractive library construction. This research was supported by grants to M.B. from the National Science Foundation (MCB-0080075) and the US Environmental Protection Agency's Science to Achieve Results (STAR) Estuarine and Great Lakes (EaGLe) program through funding to the Consortium for Estuarine Ecoindicator Research for the Gulf of Mexico (CEER-GOM; US EPA Agreement R82945801). Although the research described in this article was funded wholly or in part by the US EPA, it has not been subjected to the Agency's required peer and policy review and, therefore, does not necessarily reflect the views of the Agency and no official endorsement should be inferred.

\section{LITERATURE CITED}

Airaksinen S, Rabergh CMJ, Sistonen L, Nikinmaa M (1998) Effects of heat shock and hypoxia on protein synthesis in rainbow trout (Oncorhynchus mykiss) cells. J Exp Biol 201: 2543-2551

Bell GW, Eggleston DB, Wolcott TG (2003a) Behavioral responses of free-ranging blue crabs to episodic hypoxia. I. Movement. Mar Ecol Prog Ser 259:215-225

Bell GW, Eggleston DB, Wolcott TG (2003b) Behavioral responses of free-ranging blue crabs to episodic hypoxia. II. Feeding. Mar Ecol Prog Ser 259:227-235

Benjamin IJ, Kroger B, Williams S (1990) Activation of the heat shock transcription factor by hypoxia in mammalian cells. Proc Natl Acad Sci USA 87:6263-6267

Blake MJ, Udelsman R, Feulner GJ, Norton DD, Holbrook NJ (1991) Stress-induced heat shock protein 70 expression in adrenal cortex: an adrenocorticotropic hormone-sensitive, age-dependent response. Proc Natl Acad Sci USA 88: 9873-9877

Brouwer M, Syring R, Hoexum-Brouwer T (2002) Role of a copper-specific metallothionein of the blue crab, Callinectes sapidus, in copper metabolism associated with degradation and synthesis of hemocyanin. J Inorg Biochem 88:228-239

Brouwer M, Hoexum-Brouwer T, Grater W, Brown-Peterson N (2003) A novel cytosolic Mn-Superoxide Dismutase (MnSOD) has replaced cytosolic Cu,ZnSOD in crustacea that use copper (hemocyanin) for oxygen transport. Biochem J 374:219-228

Brouwer M, Larkin P, Brown-Peterson N, King C, Manning S, Denslow N (2004) Effects of hypoxia on gene and protein expression in the blue crab, Callinectes sapidus. Mar Environ Res 58:787-792

Brouwer M, Brown-Peterson NJ, Larkin P, Manning S, Denslow N, Rose K (2005) Molecular and organismal indicators of hypoxic stress in crustacea. In: Bortone $\mathrm{S}$ (ed) Estuarine indicators. CRC Press, Boca Raton, FL, p 267-276

Buzzelli CP, Luettich RA, Powers SP, Peterson CH, McNinch JE, Pinckney JL, Pearl HW (2002) Estimating the spatial extent of bottom-water hypoxia and habitat degradation in a shallow estuary. Mar Ecol Prog Ser 230:103-112

Choi J, Roche H, Caquet T (2000) Effects of physical (hypoxia, hyperoxia) and chemical (potassium dichromate, fenitrothion) stress on antioxidant enzyme activities in Chironomus riparius $\mathrm{Mg}$. (Diptera, Chironomidae) larvae: potential biomarkers. Environ Toxicol Chem 19:495-500

Cloern JE (2001) Our evolving conceptual model of the coastal eutrophication problem. Mar Ecol Prog Ser 210: $223-253$
Cooper SR, Brush GS (1993) A 2500 year history of anoxia and eutrophication in Chesapeake Bay. Estuaries 16:617-626

Czyzyk-Krzeska MF (1997) Molecular aspects of oxygen sensing in physiological adaptation to hypoxia. Toxicol Chem 19:495-500

Das T, Stickle WB (1994) Detection and avoidance of hypoxic water by juvenile Callinectes sapidus and C. similis. Mar Biol 12:593-600

DeFur PL, Mangum CP, Reese JE (1996) Respiratory responses of the blue crab Callinectes sapidus to longterm hypoxia. Biol Bull (Woods Hole) 178:46-54

Diaz RJ, Rosenberg R (1995) Marine benthic hypoxia: a review of its ecological effects and the behavioural responses of benthic macrofauna. Oceanogr Mar Biol Annu Rev 33:245-303

Diaz RJ, Neubauer RJ, Schaffner LC, Pihl L, Baden SP (1992) Continuous monitoring of dissolved oxygen in an estuary experiencing periodic hypoxia and the effect of hypoxia on macrobenthos and fish. Sci Total Environ (Suppl) 1992: 1055-1068

Ghoshal K, Wang YJ, Sheridan JF, Jacob ST (1998) Metallothionein induction in response to restraint stress - transcriptional control, adaptation to stress, and role of glucocorticoid. J Biol Chem 273:27904-27910

Gracey AY, Troll JV, Somero GN (2001) Hypoxia-induced gene expression profiling in the euryoxic fish Gillichthys mirabilis. Proc Natl Acad Sci USA 98:1993-1998

Gray JS, Wu RS, Or YY (2002) Effects of hypoxia and organic enrichment on the coastal marine environment. Mar Ecol Prog Ser 238:249-279

Hochachka PW, Lutz PL (2001) Mechanism, origin, and evolution of anoxia tolerance in animals. Comp Biochem Physiol 103B:435-459

Hochachka PW, Buck LT, Doll CJ, Land SC (1996) Unifying theory of hypoxia tolerance: molecular/metabolic defense and rescue mechanisms for surviving oxygen lack. Proc Natl Acad Sci USA 93:9493-9498

Hogstrand C, Balesaria A, Glover CN (2001) Application of genomics and proteomics for study of the integrated response to zinc exposure in a non-model fish species, the rainbow trout. Comp Biochem Physiol Part B 133:523-535

Justic D, Rabalais NN, Turner RE, Wiseman WJ (1993) Seasonal coupling between riverborne nutrients, net productivity and hypoxia. Mar Pollut Bull 26:184-189

Karlin S, Altschul SF (1990) Methods for assessing the statistical significance of molecular sequence features by using general scoring schemes. Proc Natl Acad Sci USA 87: 2264-2268

Kultz D (2003) Evolution of the cellular stress proteome: from monophyletic origin to ubiquitous function. J Exp Biol 206: 3119-3124

Larkin P, Folmar LC, Hemmer MJ, Poston AJ, Denslow ND (2003) Expression profiling of estrogenic compounds using a sheepshead minnow cDNA macroarray. Environ Health Perspect Toxicogenomics 111:839-846

Lewis S, Handy RD, Cordi B, Billinghurst Z, Depledge MH (1999) Stress proteins (HSP's): methods of detection and their use as an environmental biomarker. Ecotoxicol 8: 351-368

Lopez-Barneo J, Pardal R, Ortega-Saenz P (2001) Cellular mechanism of oxygen sensing. Annu Rev Physiol 63: 259-287

Mangum CP (1985) Molting in the blue crab Callinectes sapidus: a collaborative study of intermediary metabolism, respiration and cardiovascular function, and ion transport. Preface J Crustac Biol 5:185-187

Mangum CP (1997) Adaptation of the oxygen transport sys- 
tem to hypoxia in the blue crab, Callinectes sapidus. Am Zool 37:604-611

Manning, CS, Schesny AL, Hawkins WE, Barnes DH, Barnes CS, Walker WW (1999) Exposure methodologies and systems for long term chemical carcinogenicity studies with small fish species. Toxicol Methods 9:201-217

May EB (1973) Extensive oxygen depletion in Mobile Bay, Alabama. Limnol Oceanogr 18:353-366

McMahon BR (2001) Respiratory and circulatory compensation to hypoxia in crustaceans. Respir Physiol 128:349-364

Monbet Y (1992) Control of phytoplankton biomass in estuaries: a comparative analysis of microtidal and macrotidal estuaries. Estuaries 15:563-571

Officer CB, Biggs RB, Taft JL, Cronin LE, Tyler MA, Boynton WR (1984) Chesapeake Bay anoxia: origin, development, and significance. Science 223:22-27

Paerl HW, Pinckney JL, Fear JM, Peierls BL (1998) Ecosystem responses to internal and watershed organic matter loading: consequences for hypoxia in the eutrophying Neuse river estuary, North Carolina, USA. Mar Ecol Prog Ser 166: $17-25$

Rabalais NN (1998) NOAA (on-line) oxygen depletion in coastal waters. NOAA's State of the art report. Silver Spring, MD:NOAA. http://state_of_coast.noaa.gov/ bulletins/html/hyp_09/hyp.html

Ringwood AH, Keppler CJ (2002) Water quality variation and clam growth: Is $\mathrm{pH}$ really a non-issue in estuaries? Estuaries 25:901-907

Robb T, Abrahams MV (2003) Variation in tolerance to hypoxia in a predator and prey species: an ecological advantage of being small? J Fish Biol 62:1067-1081

Rose KA (2000) Why are quantitative relationships between environmental quality and fish populations so elusive? Ecol Appl 10:367-385

Rose KA, Murphy CA, Diamond, SL, Fuiman LA, Thomas P (2003) Using nested models and laboratory data for predicting population effects of contaminants on fish: a step toward a bottom-up approach for establishing causality in field studies. Human Ecol Risk Assess 9:231-257

Russell WJ, Ho YS, Parish G, Jackson RM (1995) Effects of hypoxia on MnSOD expression in mouse lung. Am J

Editorial responsibility: Otto Kinne (Editor-in-Chief), Oldendorf/Luhe, Germany
Physiol Lung Cell Mol Physiol 13:L221-L226

Sanford LP, Sellner KG, Breitburg DL (1990) Covariability of dissolved oxygen with physical processes in the summertime Chesapeake Bay. J Mar Res 48:567-590

Semenza GL (2000) HIF-1: mediator of physiological and pathophysiological responses to hypoxia. J Appl Physiol 88:1474-1480

Syring RA, Hoexum-Brouwer T, Brouwer M (2000) Cloning and sequencing of cDNAs encoding for a novel copperspecific metallothionein and two cadmium-inducible metallothioneins from the blue crab Callinectes sapidus. Comp Biochem Physiol Part C 125:325-332

Terwilliger NB, Dangott L, Ryan M (1999) Cryptocyanin, a crustacean molting protein: evolutionary link with arthropod hemocyanin and insect hexamerins. Proc Natl Acad Sci USA 96:2013-2018

Ton C, Stamatiou D, Liew C-C (2003) Gene expression profile of zebrafish exposed to hypoxia during development. Physiol Genomics 13:97-106

Turner RE, Rabalais NN (1994) Coastal eutrophication near the Mississippi delta. Nature 368:619-621

US EPA (1999) Ecological condition of estuaries in the Gulf of Mexico. EPA 620-R-98-004. US Environmental Protection Agency, Office of Research and Development, National Health and Environmental Effects Research Laboratory, Gulf Ecology Division, Gulf Breeze, FL

Vayda ME, Shewmaker CK, Morelli JK (1995) Translational arrest in hypoxic potato tubers is correlated with the aberrant association of elongation factor EF-1 alpha with polysomes. Plant Mol Biol 28:751-757

Wannamaker CM, Rice JA (2000) Effects of hypoxia on movements and behavior of selected estuarine organisms from the southeastern United States. J Exp Mar Biol Ecol 249: 145-163

Williams TD, Gensberg K, Mincin SD, Chipman JK (2003) A DNA expression array to detect toxic stress response in European flounder (Paralichthys flesus). Aquat Toxicol 65:141-157141-157

Wu RSS, Lam PKS, Wan KL (2002) Tolerance to, and avoidance of, hypoxia by the penaeid shrimp (Metapanaeus ensis). Environ Pollut 118:351-355

Submitted: July 13, 2004; Accepted: November 2, 2004

Proofs received from author(s): January 19, 2005 